Lerch, M. (2016). Internal and international migration across the urban hierarchy in Albania. Population Research \& Policy Review, 35, 851.

Lulle, A. (2019). Balkans and Baltics: On migration as a factor of regional peripheralization. Journal of Balkan and Near Eastern Studies, $21 \quad$ (1), 2742, DOI: 10.1080/19448953.2018.1532684

McCollum, D., Liu, Y., Findlay, A., Feng, Z. and Nightingale, G. (2018). Determinants of occupational mobility: the importance of place of work, Regional Studies, 52 (12), 1612-1623.

Rérat, P. (2014). Highly qualified rural youth: why do young graduates return to their home region? Children's Geographies, 12 (1), 70-86.

Rogaly, B. (2009). Spaces of work and everyday life: Labour geographies and the agency of unorganised temporary migrant workers. Geography Compass, 3, 1975-1987.

Schuster, L. (2005). The continuing mobility of migrants in Italy: Shifting between places and statuses. Journal of Ethnic and Migration Studies, 31 (4), 757-774.

Skeldon, R. (1997). Migration and Development: A Global Interpretation. London: Longman.

Smith, P.D. and Sage, J. (2014). The regional migration of young adults in England and Wales (2002-2008): a 'conveyor-belt' of population redistribution?, Children's Geographies, 12 (1), 102-117.

Torok, I. (2017). Migration patterns and core-periphery relations from the Central and EasternEuropean perspective. European Review, 25 (3), 388-405.

Wiest, K. (2016). Migration and everyday discourses: Peripheralisation in rural Saxony-Anhalt from a gender perspective. Journal of Rural Studies, 43, 280-290.

\title{
MOBILITY MOTIVATIONS AND EXPERIENCES OF HIGHLY SKILLED LATVIANS ABROAD
}

\section{Augsti kvalificētu Latvijas emigrantu mobilitātes motivācija un pieredze ārvalstīs}

\author{
Inese Šūpule \\ University of Latvia, Institute of Sociology and Philosophy \\ inese.supule@biss.soc.lv
}

\begin{abstract}
The aim of this paper is to analyse career migration of the highly skilled from Latvia in the context of post-accession migration since the EU enlargement of 2004. Based on secondary analysis of survey data, the study addresses three empirical questions: What are the motives of these highly skilled migrants, both for the initial migratory move and future mobility? What are the structural factors influencing the decisions of the highly skilled? What kinds of jobs do they actually obtain, and how do they get those jobs? The theoretical framework of the study is a synthesis of several theories, taking into account and testing the concept of liquid migration and its applicability to the career migration of the highly skilled from Latvia. The data analysis demonstrates that the concept of liquid migration does not characterise most typical migration patterns from Latvia, especially the migration patterns of the highly skilled in STEM areas. Contrary to the dominant characteristics of liquid migration, the highly skilled often choose long-term settlement and register abroad as employees.
\end{abstract}

Keywords: career migration of the highly skilled, liquid migration, post-accession migration

\section{Introduction}

Migration patterns and trends among highly qualified specialists have been investigated in many countries. At the same time, studies on the mobility of highly 
qualified specialists in Latvia are under-represented; also, studies on return migration are very few in Latvia (Krišjāne et al. 2013; Hazans 2015; Hazans 2018; Kḷave and Šupule 2015). Recent studies on emigration processes in Latvia show that the proportion of highly educated people leaving Latvia significantly increased during the years of the economic crisis of 2009-2011. Different studies show that Latvia is suffering a serious brain drain effect (Krišjāne et al. 2013: 104). Highly educated emigrants are over-represented in Science, Mathematics, IT and Medicine (Hazans 2018). Hazans also concludes that so far, return migration is not compensating the brain drain from Latvia (Hazans 2015), and emigration has contributed to a shortage of high- and medium-skilled professionals educated in Science, Mathematics, ICT and Medicine, as well as experienced engineers and technicians (Hazans 2018). In this context, it is important to analyse the career migration of the highly skilled from Latvia, their migration motives and intentions, and career development.

When Central and Eastern European countries joined the European Union in 2004, and some years later, when Western European countries removed the last restrictions for the free movement of labour, inflow of the highly skilled to Western European countries increased exponentially (ICF 2018). The individual migration decisions of all migrants, including the highly skilled, are influenced by a complex interplay of push and pull factors at macro, meso and micro level (Faist 1997; King et al. 2016). One of the strategies to enter into the labour market is studying abroad (ICF 2018). Many welleducated women from Central and Eastern European countries come to Western European countries due to their romantic relationship. At the same time, they often continue their studies in the chosen destination country and stay there thanks to their talents (Matyska 2019). As a core part of skilled migration literature, including the debates on return migration policies, a discussion on circular migration has emerged (Kuvik 2012). These discussions have been inspired by the contributions of Chinese and Indian high-tech workers to the development of their countries-of-origin (Hooper and Sumption 2016).

The theoretical framework of this study is inspired by the concept of liquid migration, and the study tests if this concept is useful for the understanding of career migration among the highly skilled from Latvia. Studies on intra-European migration indicate that the migration process after 2004 differs from the dominant migration patterns of the twentieth century (Glorius et al. 2013). Social scientists talk about new types of migrants, among them being highly qualified workers who seek employment in the Western knowledge economies (Engbersen and Snel 2013). New trends also need new theoretical concepts, and one of the new concepts characterizing current migration processes is the concept of liquid migration. According to Engbersen and Snel (2013), liquid migration is a typical phenomenon of post-accession migration, characterising contemporary labour migration patterns from Central and Eastern Europe to Western Europe, and it has six dominant characteristics: (1) the temporality of a stay abroad; (2) invisibility (the temporal nature of residence often goes hand in hand with non-registration and contributes to invisibility); (3) it is predominantly 
labour migration; (4) it is mostly regular migration; most migrants have legal residential status; (5) it is unpredictable, because labour migrants react and adapt to altering conditions in the different labour markets; (6) it is more individualistic, because there is a trend that family ties have become looser and more fragile among migrants from CEE countries. At the same time, recent studies on labour migration patterns from Central and Eastern Europe to Western Europe reveal the trend of transition to longer-term settlement and the diversity of labour migration patterns (Friberg 2012; Bygnes and Erdal 2017 etc.). The analysis of career migration among the highly skilled from Latvia aims to determine if the concept of liquid migration is applicable to the migration patterns of the highly skilled from Latvia. The analysis is focused on the first and the most important feature of liquid migration: the temporality of a stay abroad, because other characteristics are very connected to this (invisibility of migration and adaptiveness to altering conditions), or needs more in-depth analysis of societal changes. The last aspect refers especially to the question about family ties and the trend that they have become looser and more fragile among migrants from CEE countries.

\section{Data and Methods}

The data source used for the analysis of career migration of the highly skilled is an emigrant survey organized within the Project "The emigrant communities of Latvia: national identity, transnational relations, and diaspora politics". An online Internet-based method was used to engage with Latvian migrants, and the survey was organized from August to October 2014. A total of 14048 Latvian nationals from 118 countries participated in the study.

For the purpose of this particular analysis a sub-sample of labour migrants has been developed. This sub-sample includes only those who are first-generation emigrants from Latvia and who were working at the time of the survey. In total, the sub-sample has reached 7798 respondents, out of which 331 were highly skilled managers and professionals in STEM areas (Science, Technology, Engineering, and Mathematics) with a Masters or Doctoral degree.

The approach of data analysis is based on comparison of the highly skilled in STEM areas (Science, Technology, Engineering, and Mathematics) with other labour migrants from Latvia. To determine whether there is a significant difference in the answers of the two groups, Pearson's chi-squared test or Yates's correction for continuity is used.

\section{Results}

\section{Highly skilled Latvian emigrants: main characteristics}

As has been found already by other studies (Goldmanis 2015; Hazans 2015), the educational and professional structure of Latvian migration varies depending on the destination. According to survey data, highly skilled managers and professionals in STEM areas with Masters and Doctoral degrees are not concentrating in one particular 
country, but are more dispersed around different countries. This is a different trend in comparison with other Latvian emigrants, who are concentrated mostly in the UK (Table 1). However, if we look at particular states, the share of highly skilled Latvian emigrants is greater in the UK (14\%), closely followed by Germany (11\%) and the U.S. (11\%). It should be added that differences in destination countries among the highly skilled and others are statistically significant $\left(\chi^{2}=207.826, \mathrm{df}=10, \mathrm{p}=0.000\right)$.

Data analysis shows that highly skilled emigrants in STEM areas with a Masters and/or Doctoral degree are older than other labour migrants. Half of the surveyed highly skilled emigrants are aged 35-54 years (among others $-42 \%$ ). 34\% are aged 25-34 (among others - 38\%), and 16\% are older than 55 years (among others $-7 \%$ ). There are almost no highly skilled emigrants in STEM areas with a Masters and/or Doctoral degree in the age group 15-24 years (among others $-13 \%$ ). These differences are statistically significant $\left(\chi^{2}=81.498, \mathrm{df}=3, \mathrm{p}=0.000\right)$. The differences in age structure can be explained by the time necessary for the highest levels of education (Masters and Doctoral degree).

Table 1. Destination countries of the highly skilled and others

\begin{tabular}{|l|c|c|}
\hline & Other emigrants (N=7466) & Highly skilled (N=330) \\
\hline UK & 38 & 14 \\
\hline Germany & 10 & 11 \\
\hline Russia & 2 & 8 \\
\hline Sweden & 4 & 4 \\
\hline Norway & 7 & 4 \\
\hline Ireland & 9 & 22 \\
\hline Other European countries & 20 & 11 \\
\hline U.S. & 4 & 4 \\
\hline Canada & 1 & 13 \\
\hline Other & 5 & \\
\hline
\end{tabular}

$\%$ of those who have given a definite answer, $\mathrm{N}=7796$

If we look at the gender of highly skilled emigrants in STEM areas, we can see the trends characteristic in many countries (Grigoleit-Richter 2017; Kirk et al. 2017), namely, that women are less represented in this group. If among other emigrants $37 \%$ are male and $63 \%$ are female, then among highly skilled emigrants in STEM areas the share of male is $54 \%$ and the share of female is $46 \%$ (these differences are significant: $\chi^{2}=39.527, \mathrm{df}=1 . \mathrm{p}=0.000 ; \chi^{2}$ Yates $\left.=38.802, \mathrm{df}=1 . \mathrm{p}=0.000\right)$.

Highly skilled individuals in STEM areas are to be found in emigration for a longer time in comparison with others. $36 \%$ of the highly skilled are in emigration already for more than ten years (among others $-20 \%$ ). $29 \%$ are in emigration for 610 years (among others - 30\%). 35\% of the highly skilled are in emigration for five years or less (among others - 50\%). These differences are statistically significant $\left(\chi^{2}=28.513, \mathrm{df}=4, \mathrm{p}=0.000\right)$. 


\section{Career experiences of the highly skilled}

The questionnaire included two questions on the occupational position of emigrants abroad: one question was about their occupational position after the first year in emigration, and the other was about their situation now. The survey results show that $84 \%$ of the highly skilled in STEM areas were employees at the time of the survey, $9 \%$ were businessmen and $7 \%$ were self-employed. Conversely, after the first year in emigration, $21 \%$ were students and only $4 \%$ were businessmen. This means, firstly, that during their stay abroad about 5\% have managed to develop their own businesses. Secondly, the survey data confirms the findings of other studies that universities are powerful recruitment channels for highly skilled migrants (Ackers 2005).

The highly skilled in STEM areas are both in emigration and in their current job for a longer period of time. Survey data shows that $13 \%$ of the highly skilled have been working in their current organisation for more than 10 years (among others $4 \%$ ). $20 \%$ of the highly skilled have been working in their current organisation for 6 to 10 years (among others $-16 \%$ ). $24 \%$ of the highly skilled have been working in their current organisation for 6 to 10 years (among others $-28 \%$ ). $43 \%$ of the highly skilled and $52 \%$ of others have been working in their current organisation for less than three years (these differences are significant: $\chi^{2}=59.834, \mathrm{df}=3, \mathrm{p}=0.000$ ).

It is interesting that, according to the survey results, finding one's first job in emigration is very different between highly skilled emigrants and others. The most popular way of finding a first job among the highly skilled was by applying for a vacancy in a tender; $46 \%$ found their first job in this way (among others this was mentioned in $20 \%$ of cases). For others, the most popular way to find the job was with the help of friends and relatives. This was mentioned by $17 \%$ of the highly skilled and $46 \%$ of others (these differences are significant: $\chi^{2}=106.070, \mathrm{df}=4, \mathrm{p}=0.000$ ).

$97 \%$ of the highly skilled in STEM areas have a written contract and are included in the social security system of the destination country. Among other Latvian emigrants this share is slightly smaller $-88 \%$ have a written contract and are included in the social security system of the destination country (these differences are significant: $\chi^{2}=19.340, \mathrm{df}=4, \mathrm{p}=0.001$ ).

\section{Motivation for emigration and return intentions}

The questionnaire included several questions measuring the motives for emigration. After the evaluation of 16 possible reasons, respondents were asked to choose the most important one. The survey results show that the three main arguments for emigration most often mentioned are: (1) financial problems, difficulties living with a low level of income (19\%); the opportunity to earn a lot better abroad (10\%); the possibilities to develop (to get a good education and/or to build a career) (9\%).

Among highly skilled labour migrants from Latvia, the argument for emigration most often mentioned is the possibility to develop (to get a good education and/or to build a career - $24 \%$, among others - $8 \%$ ). Financial problems and difficulties living 
with a low level of income were mentioned by $4 \%$ of highly skilled (among others $20 \%$ ); the opportunity to earn a lot better $-7 \%$, among others $-11 \%$ (these differences are significant: $\chi^{2}=176.786, \mathrm{df}=17, \mathrm{p}=0.000$ ).

Table 2. Return intentions: the highly skilled and others. \%

\begin{tabular}{|l|c|c|c|}
\hline & $\begin{array}{c}\text { Highly skilled } \\
(\mathbf{N = 3 2 8})\end{array}$ & $\begin{array}{c}\text { Others } \\
(\mathbf{N = 5 7 2 4})\end{array}$ & $\begin{array}{c}\text { Total } \\
(\mathbf{N = 6 0 5 2})\end{array}$ \\
\hline Consider returning in next six months & 2 & 4 & 4 \\
\hline Consider returning in next five years & 15 & 13 & 13 \\
\hline Consider returning after retirement & 16 & 21 & 21 \\
\hline Under specific conditions & 43 & 40 & 40 \\
\hline More likely not & 12 & 14 & 14 \\
\hline Definitely not & 12 & 8 & 8 \\
\hline
\end{tabular}

$\%$ of those who have given a definite answer, $\mathrm{N}=6052$

Regarding return intentions, the answers of the highly skilled do not differ very much from others (Table 2). One of the explanations for low return intentions can be found in the critical evaluation of the possibilities for finding a decent job in Latvia. The possibility of finding a job in Latvia corresponding to one's qualifications has been evaluated as good by $33 \%$ of the highly skilled and $25 \%$ by others (these differences are statistically significant: $\left.\chi^{2}=10.921, \mathrm{df}=4, \mathrm{p}=0.027\right)$. The possibility of finding a job in Latvia with a decent salary has been evaluated even more critically. Only $10 \%$ of those highly skilled and $7 \%$ of others evaluate this possibility as good (these differences are not statistically significant: $\chi^{2}=5.276, \mathrm{df}=4, \mathrm{p}=0.260$ ).

\section{Discussion and Conclusions}

The analysis of career migration of the highly skilled from Latvia was focused on two groups: highly skilled managers and professionals in STEM areas (Science, Technology, Engineering, and Mathematics) with a Masters and/or Doctoral degree and other labour migrants from Latvia. Main arguments of particular interest about the experiences of highly skilled managers and professionals in STEM areas were based on the fact that highly educated emigrants are over-represented in Science, Mathematics, IT and Medicine, and return migration does not compensate for brain drain (Hazans 2015, Hazans 2018).

Based on secondary analysis of the survey data, the study shows that the main motive for emigration among the highly skilled is the possibility for development (to get a good education and/or to build a career), but not financial problems, which characterise the motives of other emigrants. At the same time, the opportunity to earn a lot better is also an important motive for emigration.

A brief analysis of some aspects of working life and career management of highly skilled emigrants shows important differences between the two groups. In comparison with others, the highly skilled more often choose permanent jobs and invest more time in them, and they also use different recruitment channels for finding their jobs. The most popular way to find a first job among the highly skilled was by applying for a vacancy in a tender. 
Contrary to many other issues, the return intentions of the highly skilled do not differ from other emigrants from Latvia. $2 \%$ of emigrants currently working are considering returning in the next six months, $15 \%$ are considering returning in the next five years, and $16 \%$ are considering returning after retirement. All in all, a majority of highly skilled managers and professionals in STEM areas are presently not planning to return to Latvia and are settled in the particular destination country.

From the data presented above it follows that the concept of liquid migration does not characterise current migration patterns from Latvia. In particular, highly skilled managers and professionals in STEM areas do not fit the dominant characteristics of liquid migration, defined by Engbersen and Snel (2013). Firstly, the current trend features a long-term settlement practice, not the temporality of a stay abroad. Secondly, people tend to register abroad as employees and do not stay invisible to state offices anymore. At the same time, the intra-European migration regime has some characteristics of liquid migration, namely, because it is mainly labour-motivated, and it is strongly facilitated by the free movement of workers within the EU. It can be concluded that the concept of liquid migration is not helpful for the understanding of career migration of the highly skilled from Latvia, but we can see that both structural factors and individual motives and lifecycle stages influence migration decisions on initial moves and return intentions.

The author considers that there is no one unified labour migration pattern characterising contemporary labour migration patterns from Central and Eastern Europe to Western Europe, but a diversity of different types and a complex set of factors underlying these types, which need to be explored in further studies.

\section{Acknowledgement}

This study was supported by the European Regional Development Fund, Activity 1.1.1.2 "Post-doctoral Research Aid" (No 1.1.1.2/VIAA/1/16/012; Project "Migration of highly qualified specialists: emigration and return migration in Latvia").

\section{Kopsavilkums}

Raksta “Augsti kvalificētu Latvijas emigrantu mobilitātes motivācija un pieredze ārvalstīs” mērķis ir analizēt augsti kvalificētu Latvijas emigrantu karjeras migrācijas pieredzi un novērtēt, vai tās raksturošanai ir izmantojams teorētiskajā literatūrā piedāvātais "likvīdās migrācijas" jēdziens. N̦emot vērā emigrantu aptaujas sekundāro datu analīzi, rakstā tiek aplūkoti šādi jautājumi: migrācijas motivācija, darba pieredze un atrašana, atgriešanās plāni. Empīriskajā analīzē pamatotie secinājumi kritizē "likvīdās migrācijas" jēdziena skaidrojuma potenciālu attiecībā uz pēdējos gados vērojamajiem migrācijas procesiem Latvijā, īpaši attiecībā uz augsti kvalificētiem un izglītotiem speciālistiem STEM jomās (zinātne, tehnolog̣ijas, inženierzinātnes un matemātika).

\section{References}

Ackers, L. (2005). Moving people and knowledge: Scientific mobility in the European Union. International Migration, 43 (5), 99-131.

Bygnes, S. and Erdal, M. B. (2017). Liquid migration, grounded lives: Considerations about future mobility and settlement among Polish and Spanish migrants in Norway. Journal of Ethnic and Migration Studies, 43 (1), 102-118. 
Engbersen, G. and Snel, E. (2013). Liquid migration. Dynamic and fluid patterns of postaccession migration flows. In: Glorius, B., Grabowska-Lusińska, I. and Kuvik, A. (eds.) Mobility in Transition: Migration Patterns after EU Enlargement. Amsterdam: Amsterdam University Press, 2140.

Faist, T. (1997). The crucial meso-level. In: Hammar, T., Brochmann, G., Tamas, K., Faist, T. (eds.) International Migration, Immobility and Development: Multidisciplinary Perspectives. Oxford: Berg, 187-217.

Friberg, J. H. (2012). The stages of nigration. From going abroad to settling down: Post-accession Polish migrant workers in Norway. Journal of Ethnic and Migration Studies 38 (10), 1589-1605.

Goldmanis, M. (2015). Statistisko svaru dizains pētījumā "Latvijas emigrantu kopienas". In: Mieriņa, I. (ed.) Latvijas emigrantu kopienas: Cerību diaspora. Rīga: Latvijas Universitātes Filozofijas un sociologiijas institūts, 42-65.

Grigoleit-Richter, G. (2017). Highly skilled and highly mobile? Examining gendered and ethnicised labour market conditions for migrant women in STEM professions in Germany. Journal of Ethnic and Migration Studies, 43 (16). 2738-2755.

Hazans, M. (2015). Smadzeņu aizplūde no Latvijas 21. gadsimtā. In: Mieriņa, I. (ed.) Latvijas emigrantu kopienas: Cerību diaspora. Rīga: Latvijas Universitātes Filozofijas un sociologijas institūts, 8592.

Hazans, M. (2018). An in-depth analysis of the emigration of skilled labour. Latvia. Brussels: European Centre of Expertise in the field of labour law, employment and labour market policy. https://ec.europa.eu/social/main.jsp?catId=738\&langId=en\&pubId=8132\&furtherPubs=yes"furtherPubs =yes $(20.01 .2019)$

Hooper, K. and Sumption, M. (2016). Reaching a "Fair Deal" on Talent: Emigration, Circulation, and Human Capital in Countries of Origin. Washington, DC: Migration Policy Institute.

ICF (2018). Study on the Movement of Skilled Labour. Luxembourg: Publications Office of the European Union.

King, R., Lulle, A., Morosanu, L. and Williams, A. (2016). International youth mobility and life transitions in Europe: Questions, definitions, typologies and theoretical approaches. Working Paper. Sussex Centre for Migration Research. http://sro.sussex.ac.uk/61441/1/mwp86.pdf. (01.03.2019).

Kirk, K., Bal, E. and Janssen, S. R. (2017). Migrants in liminal time and space: an exploration of the experiences of highly skilled Indian bachelors in Amsterdam, Journal of Ethnic and Migration Studies, 43 (16), 2771-2787.

Kḷave, E. and Šūpule, I. (2015). Remigrācijas procesa analīze: politika un prakse. In: Mieriṇa, I. (ed.) Latvijas emigrantu kopienas: Cerību diaspora. Rīga: Latvijas Universitātes Filozofijas un sociologijas institūts, 194-209.

Krisjane, Z.; Berzins, M. and Apsite, E. (2013). Post-accession migration from the Baltic states. The case of Latvia. In: Glorius, B., Grabowska-Lusińska, I. and Kuvik, A. (eds.) Mobility in Transition: Migration Patterns after EU Enlargement. Amsterdam: Amsterdam University Press, 85-111.

Kuvik, A. (2012). Skilled migration in Europe and beyond: Recent developments and theoretical considerations. In: Martiniello, M. and Rath, J. (eds.) An Introduction to International Migration Studies: European Perspectives. Amsterdam: Amsterdam University Press, 211-235.

Matyska, A. (2019). How far can talent take you? Polish skilled mobility as self-initiated expatriation during and after the Cold War. In: Habti, D. and Elo M. (eds.) Global Mobility of Highly Skilled People. Multidisciplinary Perspectives on Self-initiated Expatriation. Basel: Springer International Publishing AG, 147-161. 